\title{
Ethical Consciousness under Totalitarianism —Review on George Orwell's 1984
}

\author{
Xuan Qin \\ Shanghai International Studies University, Shanghai, China
}

\begin{abstract}
Since the new president of the United States Trump wield power people began to doubt the political situation, which thus led to the novel 1984 jump to the top in the list of the best seller. Public concern is that whether George Orwell's allegorical purpose will be realized. Definitely 1984 is known as an anti-totalitarian novel describing the ethical disorder, the revolting principles, the absurd disciplines and ideological deformation of the "Big Ocean" country under the domination of "Big Brother". People living there are forced to fall into ethical dilemma. They have changed their rational thoughts into irrational ones. Besides, they give up their identity of blood relatives and principles of making friends and empower irrationality to control humanity. This article intends to analyze the trauma made by the totalitarian government from the aspects of ethical consciousness.
\end{abstract}

Index Terms - 1984, ethical consciousness, totalitarian government

\section{INTRODUCTION}

The British writer George Orwell (1903-1950) has been debated continuously over the past several decades on many aspects of his works. His prominent achievements of writing on novels, documentaries, essays and criticism have established him as one of the most influential writer reflecting the hard political or social life in London. Orwell claims that it is the obligation of writers to fight against social injustice, oppression, and the power of totalitarian regimes. His view of the class-bounded language has had a deep influence on the political discourse of our time. Orwell writes to fight against any form of totalitarianism all his life, and he is called as "the conscience of his age." (Dennis, 1985, p.339)

In the theoretic structure of Ethical Literary Criticism, ethical consciousness is one of the inner core concepts. It is because of the ethical consciousness, people turn into human beings. The main character of ethical consciousness is the ability to distinguish good and evil, however, people in Big Ocean can not have that ability because of the deformation and degeneration of ethical consciousness, the loss of humanity and irrationality of ethical consciousness.

\section{LOSS OF HUMANITY AND THE USE OF ABNORMAL TECHNOLOGY}

In Big Ocean, all the beautiful things may be destroyed as long as they awaken the humanity in one's soul. Ethic is just such kind of beautiful things which is the ligament to connect people. As we can see, the quality, the beauty and dignity of life need morality, and our social existences depend on morality too. Then, how to put morality into our actions everywhere? Living under ethical consciousness is very important. Yet the target of Big Ocean is to go deeper into people's ethical consciousness to ruin the ethical system inside normal human beings. The rulers have taken strict measures such as physical and ideological deformation of ethical consciousness to constrain people's behaviors in the field of ideology.

In the modern world, some types of control and surveillance are important to keep public life safe and orderly. However, in Big Ocean, such surveillance mechanism is overdone to people, for it deprives nearly all the privacy of the people, including freedom, hobby and independent thought.

Firstly, the physical deformation of ethical consciousness is found in Big Ocean's architecture, which is superior and enormous, the so-called Panopticon according to Jeremy Bentham. Panopticon is a building like a circle and there is a tower at the center. Besides, there are a lot of large windows around the tower, facing the inner circle. Outside the building, there are some divided small rooms whose windows are facing the center tower so that the governor in the center of the tower can effectively monitor various events through the cell windows. In order to achieve a clear monitoring within the prison, some natural light is essential. Therefore, it is an interesting phenomenon: brightness but not darkness can make people under the shadow of crime. In short, the essence of Panopticon is that everyone can be observed from any angle at the center. People in a their small prison can only see something inside, which means that people can be clearly observed by someone they can not see nor imagine. The height, the shape, and the darkness in the architecture have assured the function of the stern punishment and surveillance from the government, which may also influence the ethical consciousness of the ordinary people. Meanwhile, a fine tube is necessary for it will be the connection of sound between the prison and watchtower; this tube not only manages to convey orders to the prisoners, 
but also to detect people's whispers. Consequently, in the visual and auditory range, people' words and needs may be comprehensively controlled.

The crucial mechanism of Panopticon has important consequences. First of all, the Panopticon which stands for totalitarianism is not only a symbol of supreme power, but also a great irony of bourgeois management. It is a good way for capitalists to monitor people to extract the surplus value of workers. Moreover, in this panoptic system, the high-tech has been refined, which has guaranteed the power to overwhelm people's capacity for independent thinking under the mechanism of watching and monitoring. It is like a pyramid which stands for hierarchical power. The higher the governors stand in the building, the deeper they can observe. It is also like a man standing on the top of a tower watching the whole society and all the citizens living there look like prisoners living in a prison.

Secondly, the physical deformation of ethical consciousness is found in Big Ocean's TV screen. It is another strict monitor which can be seen not only in the four main Ministries of Big Ocean but also in the daily life of the proletarians. It is regarded as a great success of the government that the giant TV screens in every citizen's room can broadcast the constant propaganda, mainly about the failures and shortcomings of the people. The TV screens also monitor behaviors everywhere; they are continuously reminded that the authorities are scrutinizing them, especially by means of the omnipresent signs "BIG BROTHER IS WATCHING YOU” (Orwell, 2001, p.560). Under that control, people are surrounded by watching, so there is no need to develop strong armaments or send large quantities of policemen. As long as there is a gaze of the eye, everything will be under control. "Through such monitoring, every individual under the pressure of such a strict watch will gradually change himself/herself into his/her own watcher consciously. Consequently, everyone is aware of self-imprisonment. What a wonderful way: rulers can get specific embodiment of power at a minimum price. This is really an effective measure in totalitarian countries. It has taken full advantage of modern science and the dexterity of technology, which can make the task of monitoring become easy, effectively and accurately.

Thirdly, the physical deformation of ethical consciousness is also found in the cruel corporal punishment. Room 101 is where the pains are centered, and people would like to do anything in order to avoid entering into that room, including giving up their basic bottom line of life.

“ 'Do anything to me!' a man yelled. 'You have been starving me for weeks. Finish it off and let me die, shoot me, hang me, sentence me to twenty-five years. Is there somebody else you want me to give away? Just say who it is and I'll tell you anything you want. I don't care who it is or what you do to them. I've got a wife and three children. The biggest of them isn't six years old. You can take the whole lot of them and cut their throats in front of my eyes and I'll stand by and watch it. But not Room 101!'” (Orwell, 2001, p.508)

As we can see, people's obedience to the principles in Big Ocean is not realized by reorganizations but by electrical punishments and strict disciplines, such as hierarchical observation, normalizing judgment and examination. There are always fears and worries when people are suffering pain or death. Thus people would like to do anything as long as they can avoid the harsh corporal punishment. On this occasion, people can't preserve national laws, regulations and basic social ethics from their heart, but from their fear. It is really not a civilized way to educate people and regulate people's behaviors. "If a man obeys the moral law out of fear, for instance, this would not be a case of moral behavior. According to Kant's perspective, the only way to have the moral behavior is to obey the moral law completely unemotionally, purely for the sake of obeying the law." (Evans, 2013, p.44) People under totalitarian threat would lose themselves totally in order to avoid suffering; they can give up anything including their ethical conscience, not to mention their relatives or friends. It is not what they would like to do, but what they have got to do. They are taught to be evil rather than kind, to hate rather than love, and to be sad rather than happy.

"Do you know what I'm going to say to them when I go up before the tribunal? 'Thank you.' I'm going to say 'thank you for saving me before it was too late."'(Orwell, 2001, p.504) We can feel that there is such a hidden promise that all the people should show their loyalty to Big Ocean since they are born. "But were you to ask the far greatest part of the nation, whether they had ever consented to the authority of their rulers, or promised to obey them, they would be inclined to think very strangely of you; and would certainly reply, that the affair depended not on their consent, but that they were born to such obedience." (Orwell, 2001, p.230) In 1984, Big Ocean is portrayed as an island prison where government monitors and controls every aspect of human life to extreme with irrational disciplinary power, aiming both to deprive the individuals' freedom and to reform them.

Except the deformation of ethical consciousness, there are also ideological deformations of Ethical Consciousness. The totalitarianism in 1984 is quite unique because it takes full advantage of ethical consciousness to ensure the stability of controlling the country. Under feudalism, people were oppressed by physical stress, so the pubic without freedom could not tell the truth. However, resistance or anger was hidden. If they were accumulated to an extreme, there would be a revolution to overthrow the old regime to build a new one. In 1984, the traditional way of controlling people's revolution is updated. They have paid attention to control the ideological ethical consciousness, believing that the control of ideology is more indispensable than physical oppression. Here, the traditional strategy of running a state has been changed into the comprehensive, free, mature and systematic one in Big Ocean. Since a stable government depends on public's support and admiration, rulers have tried hard to use high-tech to conduct a lot of activities to wash people's brains. The so-called benefits of totalitarianism can spread to everybody's perception and every corner in Big Ocean. The result is that people have no willingness to fight against the regime and they'd like to be oppressed forever. 
In addition to the single physical deformation of ethical consciousness, Big Ocean has prepared the abnormal ideological deformation of ethical consciousness for people. "So long as we are not assailed by emotions contrary to our nature, we have the power of arranging the modifications of our body according to the intellectual order." (Spinoza, 2007, p.258) However, Big Ocean has spared no gains to assail the human nature and the principles of government have nothing to do with the intellectual order. The rulers have attempted not only to destroy the sense of sympathy and human love, but also to take language as an effective way to disarrange people's perception.

To begin with, depriving people of their compassion and human love is one of Big Ocean's strategies. There is such a scene in Winston's diary showing Big Ocean's training of people's ideological deformation of ethical consciousness:

"April 4th, 1984...All war films...Audience much amused by shots of a great huge fat man trying to swim away with a helicopter after him...audience shouting with laughter when he sank." (Orwell, 2001, p.275)

This description has clearly expressed the psychology of Winston and the outside Party members: they shout with laughter when the man sank, for they are lack of compassion, not knowing how to cherish life. On the one hand, we must emphasize that the characters' numbness is not equal to the writer's apathetic consciousness; the characters' moral turpitude is not equal to the writer's indifference. It simply shows the success of the inner Party's education. Due to the inner Party's training, pure impulses and feelings are not of any value. On the other hand, the author expresses his concern about the people's helplessness, incompetence and moral turpitude. This is the epitome of ideological transformation of ethical consciousness and the beginning of the deterioration of social moral construction.

From the perspective of writing techniques and expressions, 1984 has not yet reached the high level, but its content reveals something serious and profound in human nature: the common people are wantonly ravaged and slaughtered by only a few autocratic and organized dictators due to the majority of the people's silence and blindness (Orwell, 2011). People in Big Ocean are born like the blank paper and their perception, thought and consciousness are not accepted by nature, but by the rulers' guidance and training. Their silence and blindness have come directly to meet the rulers' demands. The totalitarianism of controlling people's ethical consciousness is extremely exposed in Big Ocean; maybe, even the most violent king has never imagined such an ideological deformation of ethical consciousness. Thus, it is important to realize that "totalitarian country attempts to control people's consciousness and sensibility, just like what they have done to control people's behavior." (Orwell, 2011, p.4)

\section{LOSS OF RATIONALITY AND THE DiSTORTION OF COGNITION}

According to Ethical Literary Criticism, human ethical consciousness appears due to the adultness of people's rationality, and then people evolve from animals to human beings---a higher and independent species. The essential difference between human beings and animals is that human beings have rationality while animals don't have it. "People get their ethical consciousness due to their rationality."(Nie Zhenzhao, 2010, p.18) In Big Ocean, we may wonder such confusing questions: since people living in Big Ocean are facing physical and ideological deformation of ethical consciousness, are they still have rationality? How to understand their animal factor and rational factor in their ethical consciousness? What harm will animal factor do to the society? Answering these questions will help us better understand the essence of people's ethical confusion and the loss of rationality in Big Ocean.

Rationality is one of the important factors that can help people make proper judgment. The highest governing principle is to focus on people's inner judgment. Thus, rationality is the highest and basic principle for people to make ethical choice and judgment. In order to control people's ethical consciousness, Big Ocean has established three main kinds of irrational principles.

The first irrational principle is the prohibition against sexual behaviors. Just like what Big Ocean has done to crush the human spirit by making it react mechanically, the state will control all forms of sexual activities in order to purify the living environment. Any sex instincts will be eradicated definitely. "Its real, undeclared purpose was to remove all pleasures from the sexual behaviors... Sexual intercourse was to be looked on as a slightly disgusting minor operation, like having an enema..."(Orwell, 2001, p.333) Sexual relationship is also a kind of ethics about man and woman. Psychologists believe that the new ethical relationship between man and woman does not mean to lose control. There are some common points related to the old moral principle, which are to promote humanity and support satisfactory family life and put emphasis on everyone's responsibility for his/her own sex behavior. It is quite clear that Big Ocean will not allow the existence of such concepts of family ethic, not to mention anything about true love or family responsibility. All Big Ocean cares about is not the harmonious family ethical relationship, but whether the family relationship is easy to control or not. It is recognized that he who controls his sex can control himself very well. Accordingly, if Big Ocean can control human sex, it can control the whole human body. In Big Ocean, as for the relationship between man and woman, there ought to be no love, no natural feelings, and no human. As for the birth of children, Big Ocean has its own way. "We have cut the links between child and parent, and between man and man, and between man and woman. Children will be taken from their mothers at birth, as one takes eggs from a hen." (Orwell, 2001, p.539)

After Winston and Julia renting a room outside and having sex in the forest for several times, they are meant to pay a price for that. For no free sexual intercourses are admitted in Big Ocean. That is because sexual behavior is regarded as a behavior of rebellion. When it comes to sexual desire, it forms the thought crime. "Even to have awakened Katharine (Winston's wife in law), if he could achieve it, would have been like a seduction." (Orwell, 2001, p.336) As we can see, 
even the sexual behavior happening between husband and wife is not allowed, for Big Ocean has its own reasons to forbid sex behaviors.

"It was not merely that the sex instinct created a world of its own which was outside the Party's control and which therefore had to be destroyed if possible. What was more important was that sexual privation induced hysteria which was desirable because it could be transformed into war-fever and leader-worship." (Orwell, 2001, p.401)

Thus, if the impulsion can not be hidden as deeply as the government expected, it is risky because the inner Party has taken strict measures to put everything in its order, especially when we talk about the impulse of sex. "The sex impulse was dangerous to the Party, and the Party has turned against it." (Orwell, 2001, p.402) Suppose there are a group of normal men, they may have all kinds of natural impulses, which are necessary parts to make up the whole men, then how can they be whole men when one of the natural impulses is cut off? Sexual ethic can better embody human revolution and progress, which especially shows its correction when it surmounts classes and time confinements. Hence, sexual behavior with special function to express human wishes has its own reason to stand steadily in human civilization. The general principle of sex should be an instinct of human, while in Big Ocean sex is forbidden and oppressed. In this sense, the writer's inner intention is to judge the loss of humanity in social ethical life and bring up a series of questions about how to be a whole person, so as to put the fable into a realistic version to lighten the fundamental principles of social ethics.

The second irrational principle is the creation of Newspeak which eliminates all nuances of words' meaning. Here Orwell creates his dystopian tale of the modern state with an appendix on the fate of words under totalitarianism. "Don't you see the whole aim of Newspeak is to narrow the range of thought? In the end we shall make thought crime literally impossible, because there will be no words to express it." (Orwell, 2001, p.319) Newspeak is a kind of language which has a very slight expression because the words of Newspeak are compounded to avoid duplication. For instance, we can use not good to express badness, then, good sex means chastity, sex crime covers all kinds of perversions as well as normal intercourse and rape is equivalent to regular intercourse in a society. The same thing happens to excellent or splendid which can be replaced by plusgood or doubleplusgood. After that, people's thoughts are technologically controlled by the ruling class via making the choices of words down to a minimum. Then, people can use few words to express their unorthodox thoughts. We may not have noticed that the powerful use of language is an effective way to control society. However, Orwell has recognized that language which is used by a poet or a journalist or a dictator can hint the quality of a society. "And a manipulation of language, particular at present, affords a manipulation of the society itself..." (Karl, 1990, p.163) The result is that the next generation will never hear or see the words like badness or worse or illness because they are replaced. There is no need for them to remember so many complex words and their minds are controlled by the words which are given to them.

Besides, Newspeak can extend in double thought which can let two contradictory thoughts combine in one brain. There is no doubt that people will lose the judgment to distinguish truth and falsehood after they are trained to have double thoughts. After the training of double thought, people can understand why "war is peace". Peace is a previous normal state in society and war is also a normal phenomenon as there are ceaseless wars between Big Ocean and other countries. "Freedom is slavery" means slavery can ensure the foundation of freedom, so slavery and freedom can live harmoniously with each other, and they are both normal and necessary thoughts. "Ignorance is strength" means if people are ignorant, they may easily be kept in order. If people's lives have kept in order, the inner Party will pay more attention to strengthen the construction of the country. Such double thoughts can also explain other contradictory policies, for example, they forbid sex behavior and encourage indulgence at the same time. On the one hand, sex is forbidden, because the oppressed sexual emotion can be converted into a craze for Big Brother. On the other hand, Big Ocean has its own reason for supporting one's indulgence, for the physical indulgence can make people ignorant of politics and rationality. Besides, it can help the few inner Party members to have more material and spiritual privileges of the limited sex.

The third irrational principle is the confusion of normal logical consciousness, including rewriting rationality and taking the irrational regulation as the basic political law. In addition to what they have done to sexual behavior and people's daily language, there are so many other irrational principles. Take the question of what is two plus two for an example, all of us know the answer is four according to the logic of math, but in Big Ocean the answer could be any one as long as Big Brother agrees. After the thought reformation and trial, Winston writes two plus two equals five in his paper which successfully means the death of his rationality and the terror of political trial. What really matters is not the strictness of regulation, but the abused power of controllers. Thomas Hobbes holds that the concept of right or wrong, justice or injustice, yours or mine... are all derived from law in civilized society. If there is no law, their existence will have no meaning. However, the concept of law relies on power. If there is no power as a supporting tool, the law will lose its authority because it can not force its citizens to abide by the law (Palmer, 2011). The power of government comes prior to the law because it can guarantee the legal effect of the law. It is a normal math's law that two plus two is four, but when it encounters the power of the ruler, the math's law has to quit its arena of history.

The three features of Big Ocean's irrational manageable philosophy have presented its destruction of human rationality. "Perhaps Orwell believes too strongly in the bourgeois tradition that successfully disclosing the irrational behavior is necessary in a good political novel." (Karl, 1990, p.160) From the perspective of Ethical Literary Criticism, the difference between human being and animal is whether there is rationality. People become human beings due to 
their rationality and animals become beasts due to their irrationality. The decrease of rational factor marks the increase of animal factor. Therefore, it is necessary to discuss the rational factor and animal factor in the following.

\section{SPHINC FACTOR AND BACKWARD CIVILIZATION}

According to Ethical Literary Criticism, we are all the combination of rational factor and animal factor, thus we are existences of Sphinx factors. The animal factor has beaten rational factor not only through the weakness of human nature, such as greediness, temptation, craziness, envy, hatred or anger, but also through restraints which have destroyed personality, rationality and humanity. "Unfortunately, Orwell's main characters frequently exist only as social animals. They are indicated in terms of status, race, caste, tradition." (Karl, 1990, p.153) When we talk about the social animals, we may say they are a kind of normal humankind with too many animal factors in their soul. As can be seen, the animal factors of people in Big Ocean are obviously presented.

The integrity of man is reflected by Sphinx factor which originates from Greek mythology. It is a riddle affording an inspiration about how people can recognize themselves and the natural differences between human beings and animals, and it is also an image united by man and beast which symbolizes the human nature and the bestial nature of mankind. Professor Nie holds that "rational factor and animal factor can be combined organically. However, rational factor is a superior factor while animal factor is an inferior factor, so the former can control the latter. That is what makes human beings have ethical consciousness."(Nie Zhenzhao, 2011, p.5) In these two factors, rational factor comes first; its kernel is reasonable will. Rational factor relies on reasonable guidance and appropriate restriction of animal factor. It is rational factor that help people suppress animal behaviors and tend to follow goodness so as to let animal factor avoid violating social ethics. However, as long as we lose rational factor, animal factor will lose its guidance and restriction, and then there'll be deviation between soul and body. (Nie Zhenzhao, 2011) Sphinx factor is the key to help us better understand the difference between rational humans and animal humans under the government of Big Brother in 1984.

Even if everyone is made up from both rational factor and animal factor, the way of the combination is quite different. Although some of the animal factors may remain in human beings, under normal conditions, the rational factor which is also called rationality---the source of ethical society, can be the leading factor to restrain and teach animal factor. The so-called rationality means "correct understanding and valuable judgments of people in a particular environment. While in literature, rationality (which is usually in the form of rational will) is not only the ethical standard of ethical choice, but also the evaluation standard of the ethical choice." (Nie Zhenzhao, 2014, p.252) Thus, rationality has a feature of seeking truth and making valuable judgments. Besides, it helps people to make proper ethical choices. The essence of truth is rationality which is a thinking activity to judge, ratiocinate or to make ethical choices. Although rationality is opposite to emotionality, Mao Zedong has ever said that rationality depends on emotionality and comes from emotionality ${ }^{(1)}$. Kant has also said that "acquire happiness is definitely any rational man's limited emotional requirements." (2003, p.30) However, Big Brother wants to kill every emotional and moral mind, to make everybody here a living machine without emotionality. All Big Ocean has done aims at controlling people's rational factor and let the animal factor come first. As O'Brien said to Winston during his trial, "Ours (civilization) is founded upon hatred. In our world there will be no emotions except fear, rage, triumph, and self-abasement." (Orwell, 2001, p.539) By overmastering the thoughts and feelings of orthodoxy and oppression, rulers have turned the land into a secular hell. Here, the dystopia is presented, in which the traditional notion of Utopia as a perfect world is thus deconstructed.

Whether people can recognize the original sin of Adam and Eve when they have eaten the forbidden fruit, in fact, is dependent on ethical choices. The original sin is the understanding of the remaining animal factor in human body after liberation from animal cognition. Consequently, rationality is acquired from ethical choices (Nie Zhenzhao, 2014). People in Big Ocean are forced to make animal ethical choices and give up rationality. They can not distinguish goodness or evil, for they are living in the irrational ethical environment with confusing ethical principles. In fact, they are educated to have no family, no friendship, no love, no trust, no responsibility, and no humanity, but only a plenty of betrayals and deceptions. They have no choice but to be the slaves of irrational forces impeding the process of social civilization. "Slavery, both in the coarser and finer sense, is apparently an indispensable means even of spiritual education and discipline." (Nietzsche, 2006, p.149) Thus, under the control of great political power, people living in Big Ocean have to be the slavery of totalitarianism for they have no way to go. They become the slaveries who are no different from the bestial animals.

There is always a question about having rational factor or animal factor in Big Ocean. Big Brother has tried all his efforts to kill the kindness of people, and force them to give up their rationality, judgment of rightness and make them fall into unethical or immoral conditions. The result is that people move towards betrayal, cruelty or indifference, sternly coolness and insensitiveness. To make matters worse, people are going closer to merciless animals without any ethical consciousness. For example, after Winston is caught, he undertakes a horrible change and becomes a subhuman without any feeling, remembering, dreaming, or thinking. After wiping out every memory of Winston's rebellious past, he is living only for the worship of the tyrant. O'Brien has warned Winston: "Whatever the Party holds to be the truth is truth. It is impossible to see reality except by looking through the eyes of the Party." (Orwell, 2001, p.539) When they talk about what is two plus two, there is no sure answer. If the inner Party says that it is not four but five, then the

\footnotetext{
See http://baike.sogou.com/v155334.htm
} 
answer is five. Another example of inspiring people's animal factor is that the Party is going to kill every peaceful thought, and tries to train people to be crazy about war. The rulers bring the war within their measurable distance and they often pass the news of victory of the war to people to inspire their enthusiasm for war. "The trumpet-call had let loose an enormous volume of noise. Already an excited voice was gabbling from the TV screen, but even as it started it was almost drowned by a roar of cheering from outside." (Orwell, 2001, p.278) Here we can see the animal factor of people in Big Ocean has defeated rational factor. People are cheering for the war and applauding restless life. Obviously, Big Brother goes to another extreme way, and he tries crazily to teach everyone in Big Ocean to be an inhuman man.

In our long evolution of species, people first acquire human body through biological selection of the fittest. Then, people acquire ethical consciousness through ethical choices. Continually, people finish the progress from animal to human. After ethical choices, the animal factor doesn't go away, but it just remains in unbounded situation. If the animal factor can not be suppressed successfully, the civilization of the society would be backward or shaken. As Elias said in The civilizing Process, civilization is the process of human society toward a certain direction during which it tries to change human behaviors and feelings. Social compulsory is gradually transformed into personal compulsory. In our behaviors, physical and sensory learning and experiences are accepted through continuous education and civilizing process, in that case, the animal nature or individualism will be suppressed (Elias, 2000, p.312-316). That means education, training and guidance are necessary in the process of civilization. Thus, animal factor has been hidden for a long time during the social civilization. But it is called back to take the place of human factor in Big Ocean. It is clearly the retrogression of the evolution of human civilization and a failure in ethical selection. Besides, it is also a wake-up call for today's people.

In 2011, Professor Nie Zhenzhao presented us the logical evolution of human civilization in the article entitled "Ethical Choice and Sphinx Factor". He believes that the evolution of human civilization is logically divided into three stages:

1. Biological selection is based on Darwin, which is also called natural selection---survival of the fittest. He believes that the first human biological selection does not solve the fundamental problem of what is human, and no men are essentially distinguished from beasts.

2. Ethical selection is accompanied by the Sphinx factor, including mutual struggles of human factor and animal factor.

3. Scientific selection is a choice based on science and technology, which focuses on science and technology with the political power system. (Nie Zhenzhao, 2011, p.2)

The third phase is the current and future requirements of society, and it is about the salvation of human nature and the ecological drawbacks during technological development.

1984 has described the animal factor in ethical consciousness because people living there have lost the quality of distinguishing between good and evil. This quality is a landmark on the evolutionary history of human civilization. Adam and Eve can tell good and evil after eating the forbidden fruit, because they were rational already at that time, and they had changed from the so-called human in biology to human with ethical consciousness. The ability to distinguish good and evil is an indispensable feature of ethical consciousness which is the key to distinguish human or animal. Generally, the concept of good or evil goes simultaneously with ethical consciousness which is a principle only for human, and we do not evaluate good or evil when we talk about beast. Therefore, "good and evil are the foundation of human ethics." (Nie Zhenzhao, 2014, p.35) The same thing happens in the famous Chinese classic Journey to the West. After Sun Wukong finishes the ethical selection with the control and guidance of iron ring on his head, he becomes a rational human or a celestial being in the novel instead of a small monkey. Being kind and human becomes Sun Wukong's final choice.

On the one hand, 1984 has described the animal factor in ethical consciousness because people living there have lost their active consciousness. The reason why people become human beings is mainly that they have consciousness while animals don't have that. "Consciousness is a kind of substance that can slide into our brain without mind-stuff, mind-dust or soul." (Blackmore, 2008, p.141) Since consciousness has such kind of quality, it is extremely difficult to be changed, because it can not be easily caught. People in Big Ocean do not have any subjectivity, for they are not allowed to perceive the world by nature and they have no mental space to reflect on themselves (Blackmore, 2008). If the ability of perceiving the world is removed, isn't it a rupture of relationship between people and nature? It is a retreat in human revolution as well. Procedures of human evolution do not always agree with the evolutionary ideas put forward by Darwin or Huxley, on the contrary, it often goes to the opposite side and has the trend of degradation. Therefore, the evolution may be a failure if it is left unchecked, which would make the offspring go far away from the civilized way. The human race is superior to other animals under biological selection, but that does not mean human will still be successful in ethical selection.

On the other hand, 1984 has described the animal factor in ethical consciousness because people living there have lost their pursuit of happiness. However, Big Ocean tries every possible way to rob people's rationality, decrease everyone's benefits and destroy everyone's happiness. If they refuse to follow, there are lots of painful trials waiting for them until they die or are forced to become irrational. That's the retreat not only in human beings, but also in human civilization, which has led human to go back to the state of animal. As we can imagine, if we come to visit Big Ocean, 
we are not going into a normal human society, but simply a zoo full of animals with human appearances, sounds of machines, perfected govern equipments and high level specifications.

We believe that Orwell does not want to criticize all the basic ethical principles for all they have done in some degree are to secure the development of society. There may be some humanity when O'Brien closes the TV screen to have a deep talk with Winston. Winston and Julia who try their hard to pursue personal enjoyment have showed their faith in each other at the very beginning. When Winston recollects his mother and sister, he believes his mother has showed humanity at the hardest time. When Winston robbed all the chocolate from his mother and sister, "his mother drew her arm round the child and pressed its face against her breast" (Orwell, 2001, p.432). This phenomenon has presented us the mother's guilty for her child because she can not give her child a comfortable life. Although the mother's behavior has no significance, we can feel her deep love. Besides, Winston also finds that in Big Ocean proletarians are of more human traits than other Party members. Although they are under cruel oppression, they keep human emotion. "The proles had stayed human. They had not become hardened inside. They had held on to the primitive emotions which he himself had to re-learn by conscious effort" (Orwell, 2001, p.434). We can feel that not all things are progressing to the opposite side of final moral. Here Orwell does not intend to criticize the entire ethical society, but simply the means, the facts, and the beliefs in the inner Party members who want to destroy human mind and deceive people. Those beliefs are going away from the final level of ethic, hindering the development of society, decreasing everyone's benefits and destroying everybody's dream of happiness.

\section{REFERENCES}

[1] Blackmore, S. (2008). Consciousness: An Introduction. Beijing: Chain Light Industry Press.

[2] Blackmore, S. (2013). Consciousness. trans. Xu Gui. Beijing: Foreign Language Teaching and Research Press.

[3] Dennis, P. (1985). Twentieth Century Literary Criticism. Detroit: Gale Research Company.

[4] Elias, N. (2000). The Civilizing Process. Oxford: Blackwell Publishing.

[5] Evans, D. (2013). Emotion. Beijing: Foreign Language Teaching and Research Press.

[6] Fromm, E. (1961). Afterword in 1984. New York: The New American Library.

[7] Hall, Sharon K. (1982). Twentieth-Century Literary Criticism. Detroit: Gale Research Company, Book Tower.

[8] Karl, F. R. (1990). A Reader's Guide to the Contemporary English Novel. New York: Farrar, Straus \& Giroux, LLC.

[9] Locke, J. (2007). An Essay Concerning Human Understanding. trans. Tan Shanming and Xu Wenxiu. Xi'an: Shanxi Peope's Publishing House.

[10] Millett, K. (1970). Sexual Politics. New York: Ballantine Books.

[11] Mordell, A. (2006). Erotic Motives in Literature. Liu Wenrong Trans. Shanghai: Wenhui Press.

[12] Niebuhr, R. (1998). Moral Man and Immoral Society. Trans Jiang Qing et al. Guiyang: People's Publishing House.

[13] Norbert, E. (2009). Uber den Prozess Zlivilixation. Shanghai: Shanghai Translation Publishing House.

[14] Oldsey, Bernard. (1983). Dictionary of Literary Bibliography. Detroit: Gale Research Company, Book Tower.

[15] Orwell, G. (1995). A Collection of Essays. trans. Dong Leshan. Beijing: China Broadcast and Television Publishing House.

[16] Orwell, G. (2001).Nineteen Eighty-Four. trans. Liu Zigang \& Xu Huiyan. Beijing: China Zhigong Publishing House..

[17] Orwell, G. (2011). George Orwell. Beijing: People's Literature Publishing House.

[18] Palmer, D. (2011). An Introduction to Ethical Theory. Shanghai: Academy of Social Sciences Press.

[19] Spinoza, B. (2007). De Ethics. Li Jian trans. Xi'an: Shan Xi People Publishing.

[20] Sumin, Nie. (2008). On the "Abnomity" of the Totalitarian From 1984. World Literature Review. 1, 47-49.

[21] Sumin, Nie. (2014). 1984: A Metaphorical Ethical Novel on Social Politics. Foreign Literature Studies. 1, $120-123$.

[22] Zhenzhao, Nie. (2010). Ethical Literary Criticism: Its Fundaments and Terms. Foreign Literature Studies. 1, 12-22.

[23] Zhenzhao, Nie. (2011). Ethical Literary Criticism: Ethical Choice and Sphinx Factor. Foreign Literature Studies. 6, 1-13.

[24] Zhenzhao, Nie. (2004). Ethical Literary Criticism: Study Method on Literary Criticism. Foreign Literature Studies. 5, 16-24.

[25] Zhenzhao, Nie. \& Du, Juan \& Hongwei, Tang. \& Weihong, Zhu. (2007.) Ethical Criticism on English Literature. Wuhan: Central China Normal University Press.

[26] Zhenzhao, Nie. (2014). Introduction to Ethical Literary Criticism. Beijing: Peking University Press.

[27] Zhongzai, Zhang. (1996). After 10 Years--Critics on George Orwell's 1984. Foreign Literature. 1, 66-71.

Xuan Qin, a PhD Candidate studying at English Department of SISU for her Doctor Degree. The professional direction is English Language and Literature. The contact address is Shanghai International Studies University, 550 Dalian West Road, Shanghai, 200083, China.

She has published two articles: the first one is "Conversion of Ethical Identity under Patriarchy-Analysis of Edith Wharton's Novella Summer" (Journal of Ludong University, 2015, 1), the other one is "Place Shift and Self-construction-Analysis of Virginia Woolf's Novel Mrs. Dalloway" (Language, literature and translation studies album, 2016). 